\title{
Assessment of Priorities of Construction of High- Speed Rail in the Czech Republic in Terms of Impacts on Internal and External Integration
} Vilém Pařil, ${ }^{1}$ Milan Viturka ${ }^{2}$

\begin{abstract}
The priorities assessment for the planned construction of high-speed rail/HSR in the Czech Republic in terms of impacts on internal and external integration is a though-provoking topic not only from the technical and economic, but also from the social and geographical point of view. Its primary basis is the application of the gravity model, according to which the planned route $\mathrm{C}$ Prague-Wien has the most significant potential in passenger transport. Then following routes are A Prague-Berlin, B PragueMünchen, and D Brno-Katowice. Subsequently, the likely impacts generated by a significant improvement in the quality parameters and hence the competitive position of rail transport were assessed, including the potential for shifting part of the demand from the road and air transport to HSR. Overall, however, it can be stated that the potential impacts of the HSR on the growth of passenger transport in the Czech Republic will not be essential. To perceive the regional impacts of HSR construction, analyses of selected indicators (population density per $\mathrm{km}^{2}$, GDP per capita, unemployment rate) by NUTS 3 regions for the period 2007-2017 were also carried out. From the strategic point of view, the research results did not confirm that the planned construction of the HSR primarily stimulates convergence tendencies in regional development as the main priority of EU regional policy. Rather, it seems more likely that the HSR will stimulate the extraction of economic activity from "rural" regions in favour of metropolitan regions.
\end{abstract}

Keywords: gravity model, high-speed rail / HSR, integration, metropolises, project.

JEL Classification: O18, R42

Received: 30 January 2020 / Accepted: 3 June 2020 / Sent for Publication: 9 June 2020

\footnotetext{
${ }^{1}$ Masaryk University, Faculty of Economics and Public Administration, ITREGEP, 60200 Brno, Czech Republic, vilem@econ.muni.cz

${ }^{2}$ Masaryk University, Faculty of Economics and Public Administration, Department of Regional Economics and Administration, 60200 Brno, Czech Republic, viturka@econ.muni.cz
}

(C) 2020 by the authors; licensee Review of Economic Perspectives / Národohospodářský obzor, Masaryk University, Faculty of Economics and Administration, Brno, Czech Republic. This article is an open access article distributed under the terms and conditions of the Creative Commons Attribution 3.0 license, Attribution - Non Commercial - No Derivatives. 


\section{Introduction}

In recent years, the issue of high-speed railways has been met with growing interest from the professional sphere. Undoubtedly, important research topics include the evaluation of their economic, territorial, and environmental contexts and relationships. From the point of view of the Czech professional public, the book Rychlá železnice i v České republice [Fast railways even in the Czech Republic] as well played an important role in this regard (Šlegr et al., 2012). From other domestic authors, it is possible to mention e.g., L. Týfa (2012), M. Körner (2013), and P. Čech (2018). From a group of foreign authors, we then consider it appropriate to mention D. Albalate (2010), Ch. Nash (2015), Y. Hollander (2016), P. Beria (2017), F. Xu (2018), and A. Zurkowski (2018). Regarding the relationship between the development of the HSR and the economy, it can be stated that with increasing practical experiences, the original idea of its important stimulating role has been revised. The significant examples confirming the original assumption occur only sporadically (e.g., French TGV route Paris-Lyon; MEDDE, 2015). However, even in the case of Japan, the proximity to HSR does not appear to have a direct effect on regional or local production or productivity (Wetwitoo, Kato, 2019). On the other hand, the launching of HSR can bring positive impacts on buyer-seller links assuming comparative lower travel costs (Bernard et al., 2019). HSR routes do not seem to increase territorial cohesion, but rather they promote territorial polarization. In other words, the relevant studies do not allow a causal relation to be established between HSR and local growth (MEDDE, 2015). It is clear that the construction of HSR should focus on connecting densely populated metropolitan areas, suffering severe road congestion problems eventually deficient air link (Albalate, Bel, 2010). In this context, it is worth mentioning a significant impact of HSR on commuting confirmed in Germany where reduction of travel time by $1 \%$ raises the number of commuters among regions by $0.25 \%$ (Heuermann, Schmieder, 2019). Also interesting is a study from Austria where HSRs are designed for lower speeds, which is countervailed by optimal integration of timetables (Brezina, Knoflacher, 2014). Another interesting example is the analysis of station location of mid-sized cities connected to HSR in terms of the location of central business districts that attract enough passengers carried out in South Korea (Kim et. al., 2018).

The high social relevance of the topic results from the fact that the construction of express transport infrastructure in the Czech Republic is rightly criticized as a nontransparent and inefficient process, where the public interest has been largely relegated. This fact is documented by the lack of a well-conceived conception of the construction of high-speed rail (known under the abbreviation HSR), to which our research seeks to contribute. In this context, the article focuses on the assessment of the effectiveness of the planned HSR construction in terms of the integration criterion with an emphasis on the perception of relevant relations. The term HSR usually refers to new railway lines with an operating speed in passenger traffic of 200 or more $\mathrm{km} / \mathrm{h}$; the term fast connection/FC with an operating speed of $160-200 \mathrm{~km} / \mathrm{h}$ is also used, including modernized conventional lines (see the Program for the Development of fast rail connections approved by the Czech Government in 2017). In the following text, given the relatively frequent combination of newly constructed and modernized railway sections, the more familiar term HSR is preferred (see, e.g., International railway association, 2007). In addition to the integration criterion, the methodology developed to assess the effectiveness of transport projects also includes relevance (technical benefits), usefulness (eco- 
nomic benefits), stimulation (regional impacts), and sustainability (environmental impacts). This original approach, validated on the evaluation of the effectiveness of Czech motorway construction projects (Viturka, Pařil, 2015), seeks to effectively link the political, technical, economic, regional, and environmental aspects of the evaluation to define relevant priorities objectively. From a broader perspective, the assessment of effectiveness reflects the $3 \mathrm{E}$ principle (effectiveness, economy, efficiency). Its significance is well reflected in the quotation of the management guru P. Drucker "effectiveness is doing the right things, and efficiency is doing things right" (Drucker, 2000). This logically implies that purposeless projects cannot be effective.

At the end of the introductory chapter, it is worth noting that the assessment of the effectiveness of infrastructural projects is not legally enshrined in the Czech Republic and their implementation is often justified only by general proclamations of their social benefit, or better based on more or less speculative estimates of future costs and benefits through CBA. Assessment of effectiveness is particularly relevant for costly transport infrastructure construction plans where it is necessary to have as comprehensive information as possible about their potential benefits to minimize the risks associated with the selection of inappropriate projects.

\section{Methods and data}

The assessment of the effectiveness of HSR construction is complicated by the fact that transport demand is primarily determined by external factors (Ellegård, Svedin, 2012), and therefore it is a derived demand. Moreover, the structure and nature of the spatial impact of social and economic factors on the development of passenger and freight transport are significantly different, and many relevant data are not available (Ministry of Transport of the Czech Republic, 2016). These facts, combined with the necessary systematic approach to planning the development of the rail network, significantly reduce the informative ability of traffic forecasts (Szczuraszek, Iwanowicz, 2019; Cats, Gkioulou, 2017), particularly in the case of freight transport with the insufficiently developed methodology for their processing (Abate et al., 2018, Shiqui et al. 2019). Our approach is therefore based on the expert perception of the potential effects of the planned projects, according to the above evaluation criteria, from which we will further discuss the integration criterion. The primary attention is then focused on the positive impacts of qualitative changes in railway infrastructure parameters on the demand and competitiveness of railway transport. It is a contradiction of current forecasts oriented to extrapolation of development trends, taking into account the expected changes in the intensity and direction of the effect of selected factors. In general, it is thus a transition from continuity preference to discontinuity preference, generated by the introduction of significant technical innovations, whose potential impacts cannot be predicted on the basis of standard forecasting models. An essential argument for applying the described approach is its broader theoretical anchoring through the original theory of integrated and sustainable regional development, which allows correct identification of poles and development axes as development-bearing spatial structures (Viturka, 2011). On the other hand, its main disadvantage is limited space for the application of more sophisticated analytical methods. The central spatial dimension of the assessment of the effectiveness of the planned intentions of HSR construction is represented by the Central European macro-region with a historically formed network of metropolises of transna- 
tional importance as the main concentrations of transport demand. From the perspective of the Czech Republic, the diverse connections of Praha, as the only fully-fledged Czech metropolis with the metropolises of neighbouring four countries, play a crucial role. In this respect, there are a total of 21 metropolises, which were based on the factors "population", "economic profile" and "business attractiveness" divided into three groups (Viturka et al., 2015): dominant (Berlin, München, Frankfurt am Main, Hamburg, conurbation Rhein-Ruhr), established (Stuttgart, Nürnberg, Hannover, Mannheim, Wien, Warszawa, Katowice) and elementary (Dresden, Leipzig, Bremen, Wrocław, Poznań, Kraków, Łodż, Gdańsk, Bratislava) metropolises.

The population size of the major metropolises of the developed countries, which are after the second demographic transition, is usually considered to be 1 million inhabitants; in the case of minor metropolises, the limit of 500 thousand inhabitants (see, e.g., Brezzi et al., 2012). In international analyses of metropolises, it is obviously necessary to ensure the comparability of their territorial delimitation. This condition is best met by OECD data, which is based on the so-called functional urban areas/FUA, made up of the core and its hinterland defined according to commuting processes (OECD, 2019b). FUAs are divided into four categories: 1. large metropolitan agglomerations with more than 1.5 million inhabitants - the major metropolises, 2. metropolitan agglomerations with 0.5-1.5 million inhabitants - the minor metropolises, 3. medium-sized nonmetropolitan agglomerations with 0.2 to 0.5 million inhabitants; and 4 . small nonmetropolitan agglomerations with 0.05 to 0.2 million inhabitants. The application of the developed methodology to assess the effectiveness of planned HSR projects logically emphasizes the links between Praha and the Czech minor metropolises, i.e., Brno and Ostrava (weakening position), and also links with the nearest foreign main metropolises. Specifically, the routes are:
A Praha - Ústí n. L. - Dresden $\rightarrow$ Berlin,
B Praha - Plzeň $\rightarrow$ München,
C Praha - Jihlava - Brno $\rightarrow$ Wien,
D Brno - Ostrava $\rightarrow$ Katowice.

Due to unclear ideas about the potential benefits of construction, the discussed Praha Wrocław direction was not included in the assessment (for similar reasons, the branch to Most was also not analysed, these two lines are currently not achieving any progress in planning or implementation process and seems to have lost political emphasis). In all cases, intermediate FUAs of the third category are included and, in the case of the Czech Republic, also FUAs of the fourth category, which takes into account considerably higher intensity of domestic than international passenger transport interactions (Körner, 2013). The relative intensity of inter-settlement links is generally highest within the so-called nodal micro-regions with a dominant share of commuting to work and to schools (with increasing hierarchical level, these regular trips are gradually replaced by irregular, especially business and tourist trips). The selection of relevant foreign metropolises generally respects the effective distance criterion, established in the most important road transport sector on the basis of European Union regulations of working time of truck drivers, which corresponds to a maximum daily distance travelled between 600 and $700 \mathrm{~km}$. In the case of rail freight transport, the effective transport distance is around $600 \mathrm{~km}$ (Ministry of Transport of the Czech Republic, 2016). This distance also largely corresponds to the real limit of the competitiveness of high-speed rail passenger 
transport compared to air transport (Seidenglanz, 2009) - accordingly, Warszawa, whose distance from Prague clearly exceeds $600 \mathrm{~km}$, was not included into analyses. To measure the comparative significance of spatial interactions from which the passenger demand is derived, the latest available population data from 2016 was used (2019a), due to the complicated methodology of defining FUA, requiring a particular survey derived from the census. Other necessary data were then taken over from the Czech Railways Company and further from the Ministry of Transport of the Czech Republic and other relevant sources (Ročenka dopravy ČR, 2017; The Federal statistical office Wiesbaden, 2018).

\section{Results}

The application of the integration criterion provides information on significant factors affecting the potential benefits of the construction of planned HSR routes in the long term and, in this context, also take into account the socio-politically important factor of international prestige assessed in terms of the implementation of the European Union transport policy. In this context, it is necessary to analyse in the first place the fundamental impact of the overall nature of the national urban system on the development of rail passenger transport. This influence is manifested, especially within the spatial systems formed by not very distant metropolitan agglomerations supplemented by intermediate non-metropolitan agglomerations with 200 thousand and more residents (considered, for example, in Germany as the lower indicative threshold for the FUA direct connection to the HSR network). Basic information can be obtained by applying a relevant variant of the gravitational model that describes well the general logic of longdistance traffic flow formation (Anderson, 1979; Halás, M., Kraft, S., 2015):

$$
G_{i j}=\frac{P_{i} \times P_{j}}{d_{i j}},
$$

where $G_{i j}=$ the gravitational force acting between metropolitan and non-metropolitan agglomerations, $\mathrm{P}_{\mathrm{ij}}=$ the settlement importance of FUA and dij $=$ the distance of FUA (measured along the existing railway routes in the direction corresponding to the planned HSRs). It should be noted that in Table 1, the ratio of domestic and international passenger rail transport intensity was set at 1: 0.2 in accordance with the analyses carried out and taking into account the development trends (Transport Yearbook of the Czech Republic, 2017). This corresponds with available researches on border effect in long-distance transport that show the decrease of passenger transport demand on crossborder connections (see, e.g., Klodt, 2004; Hazledine, 2009). In the broader international context of the planned HSR, it is necessary to mention the Trans-European Transport Network (TEN-T) integrating road, railway, water and aviation infrastructures of the European Union, approved by the European Commission in 1990. In our case, these are mainly corridors passing through the Czech Republic i.e., The Orient/ EastMediterranean corridor Hamburg - Berlin - Praha - Budapest -Timișoara - Sofia Athens and The Baltic-Adriatic corridor Gdańsk - Warszawa - Brno/Bratislava - Wien - Venezia - Ravenna (from corridors passing through neighbouring countries is especially important for the Czech Republic the Rhine-Danube corridor Strasbourg - München - Wien - Bratislava - Budapest - București and the Scandinavian-Mediterranean Corridor: Helsinki - Stockholm/Oslo - København - Berlin - München - Innsbruck Roma - Napoli. 
From the specific questions, it is necessary to mention the politically sensitive problem of connecting the regional town of Jihlava (defined by FUA 4th category includes the town of $\mathrm{H}$. Brod together with five rural municipalities) to the planned HSR route Praha - Brno - Wien. In this direction, the Praha - Kolín - Jihlava variant, with a terminal located at the D1 motorway between H. Brod and Jihlava, is preferred (we consider the second discussed variant of the HSR line from Praha through Benešov unrealistic due to unsuitable construction conditions).

Table 1. The gravity of metropolis and selected FUA

Route A

Route B

\begin{tabular}{|c|c|c|c|c|c|}
\hline $\begin{array}{l}\text { metropolis/ } \\
\text { other FUA }\end{array}$ & $\begin{array}{l}\text { population (in } \\
\text { thousands) }\end{array}$ & $\begin{array}{l}\text { distance to } \\
\text { Praha }(\mathrm{km})\end{array}$ & $\begin{array}{c}\text { metropolis/other } \\
\text { FUA }\end{array}$ & $\begin{array}{l}\text { population (in } \\
\text { thousands) }\end{array}$ & $\begin{array}{l}\text { distance to } \\
\text { Praha (km) }\end{array}$ \\
\hline Praha & 2178 & $x$ & Praha & 2178 & $x$ \\
\hline Ústí n. L. & 120 & 106 & Plzeň & 343 & 113 \\
\hline Dresden & 1344 & 192 & Regensburg & 446 & 296 \\
\hline Berlin & 5066 & 397 & München & 2849 & 434 \\
\hline$\sum G_{i j}$ & \multicolumn{2}{|c|}{11867} & $\sum G_{i j}$ & \multicolumn{2}{|c|}{10903} \\
\hline \multicolumn{3}{|c|}{ Route C } & \multicolumn{3}{|c|}{ Route D } \\
\hline $\begin{array}{l}\text { metropolis/ } \\
\text { other FUA }\end{array}$ & $\begin{array}{c}\text { population } \\
\text { (in thousands) }\end{array}$ & $\begin{array}{l}\text { distance to } \\
\text { Praha }(\mathrm{km})\end{array}$ & $\begin{array}{l}\text { metropolis/ } \\
\text { other FUA }\end{array}$ & $\begin{array}{c}\text { population } \\
\text { (in thousands) }\end{array}$ & $\begin{array}{l}\text { distance to } \\
\text { Praha }(\mathrm{km})\end{array}$ \\
\hline Praha & 2178 & $x$ & Brno & 724 & $x$ \\
\hline Jihlava & 100 & 136 & Ostrava & 717 & 172 \\
\hline Brno & 724 & 256 & Katowice & 2541 & 265 \\
\hline Wien & 2823 & 404 & & & \\
\hline$\sum G_{i j}$ & \multicolumn{2}{|c|}{14381} & $\sum G_{i j}$ & \multicolumn{2}{|c|}{8324} \\
\hline
\end{tabular}

Source: OECD (2019a), own calculations.

Notes:

1. The major metropolis, the minor metropolis, other FUA (the last available figure is for 2016).

2. Model relations of Czech and foreign FUA are weighted by 0.2 coefficient.

3. Intra-German relations not included.

According to model aggregations of passenger transport potential, the route $\mathrm{C}$ (with a $43 \%$ share of cross-border gravitational force) is the best positioned in the integration criterion, followed by routes A (79\%), B (39\%) and D (64\%). The obtained data can be practically used for objectifying perspective considerations on the competitiveness of rail transport against road and air transport. In this respect, attention should be drawn to the so-called induced demand phenomenon generated by the commissioning of HSR, which is most often estimated by foreign experts in the range of 10 to $20 \%$ of basic demand (Feigenbaum, 2013). The highest level of this demand is most likely to be expected on route $\mathrm{B}$. In view of the long construction deadlines, the concept, and planning of construction development of the HSR network should also take into account the population development of the respective residential centres. Of these centres (FUA), the highest growth rates of demographic growth, in the Czech Republic in the period of 2000-2016, were recorded in Praha and Plzeň (population growth of approximately $12 \%$ 
and $4 \%$ respectively (just for comparison - Ostrava recorded a population decrease of $6 \%$ ); compared to some foreign centres, such as, e.g., München and Wien (population increase of 16 and $15 \%$ respectively), followed by Regensburg (an increase of $9 \%$ ).

The construction of HSR is of considerable importance also for the formation of "express" lines of rail freight transport, facilitating the development of business interactions as key determinants of the developmental differentiation of social systems on the transnational or global hierarchical level. However, the spatial links of freight transport, much more than in the case of passenger transport, are influenced by specific factors reflecting production and consumer links, within them the economic efficiency of particular countries or regions together with their integration into global production networks play ever more important role. These facts considerably limit the possibilities of application of forecasting models in the case of development of rail freight transport, which is usually based on the premise for maintaining its current scope (Jedlička et al., 2014). The spatial specifics of demand for transport can be documented on the example of Germany as by far the most important trading partner of the Czech Republic with roughly $30 \%$ share in its foreign trade. Within this framework, according to the Czech Embassy in Berlin the six most important German Bundesländer account for approximately $86 \%$ of total trade turnover with the Czech Republic and $61 \%$ of its exports: of which Bayern 29/16\% (16\% of the German population), Baden-Württemberg 19/14 \% (13\%), Nordrhein-Westfalen 14/14\% (22\%), Niedersachsen 8/8 \% (10\%), Sachsen 10/5\% $(5 \%)$ and Hessen $6 / 4 \%(8 \%)$. From the available data, the best position of the planned route $\mathrm{B}$ is apparent, followed by the second "German" route $\mathrm{A}$ and by the remaining routes $\mathrm{C}$ and $\mathrm{D}$ at a significant distance. The analysis confirms the lower predictive ability of the gravity model application, for freight transport, where we would obtain, in case of using the indicator of generating the GDP for valuing the economic importance of regions, different order of routes A, C, B and D. The declared objective of EU transport policy is to move $30 \%$ of freight transport performance over $300 \mathrm{~km}$ distance from road to rail and water transport by 2030 (European Commission, 2011). From the perspective of the Czech Republic, however, this goal is difficult to achieve, which is also due to the negligible importance of water transport with less than $1 \%$ of the total output (the possibility of changing this situation with the help of the long-term debated project of the Dunaj - Odra - Labe rivers canal is outside the boundaries of technical and operational-economic reality). Given the small size of the Czech Republic, the possibility of combined use of planned HSR for the needs of international passenger and freight transport can be considered in perspective. However, based on the available information, it can be stated that the realization of this option seems to be unlikely. 
Table 2. Position of rail transport in the Czech Republic

\begin{tabular}{lccccc} 
Type of transport performance & $\mathbf{2 0 1 3}$ & $\mathbf{2 0 1 4}$ & $\mathbf{2 0 1 5}$ & $\mathbf{2 0 1 6}$ & $\mathbf{2 0 1 7}$ \\
\hline Percentage of passenger transport in \% & 3,7 & 3,7 & 3,6 & 3,5 & 3,5 \\
rail transport & 7,2 & 7,4 & 7,2 & 6,6 & 6,3 \\
bus transport & 0,1 & 0,1 & 0,1 & 0,1 & 0,1 \\
air transport & 46,2 & 45,3 & 44,4 & 45,0 & 44,5 \\
urban transport & 42,7 & 43,5 & 44,7 & 44,8 & 45,5 \\
individual car transport & & & & & \\
Share in transport performance (pkm) & 7,1 & 7,1 & 7,3 & 7,4 & 7,6 \\
rail transport & 8,4 & 9,1 & 8,8 & 8,6 & 9,0 \\
bus transport & 8,9 & 8,8 & 8,5 & 8,6 & 9,1 \\
air transport & 15,2 & 14,8 & 14,1 & 14,6 & 14,3 \\
urban transport & 60,3 & 60,2 & 61,2 & 60,7 & 59,9 \\
individual car transport & & & & & \\
Share in freight transport in \% & 18,8 & 18,7 & 17,7 & 18,2 & 16,9 \\
rail transport & 78,6 & 78,6 & 79,9 & 80,1 & 80,5 \\
road transport & 2,3 & 2,4 & 2,0 & 1,4 & 2,4 \\
pipeline transport & & & & & \\
Share in transport performance (tkm) & 19,5 & 20,4 & 19,9 & 22,9 & 25,2 \\
rail transport & 76,8 & 75,7 & 76,6 & 73,8 & 70,3 \\
road transport & 2,7 & 2,9 & 2,6 & 2,3 & 3,4 \\
pipeline transport & & & & \\
\hline Source: Transport Yearbo 0 (the & & & &
\end{tabular}

Source: Transport Yearbook of the Czech Republic (2017), own calculations

Note: The different methodology of data production in rail transport is not taken into account; water transport and air transport are not included.

Before the final discussion of the broader context of the analysis of the planned HSR, it is useful to make a few remarks on the competitive position of rail transport in the transport system of the Czech Republic. The table above documents the stabilization of the development of the railway's share in passenger transport (at present it is slightly increasing, which is, however, stimulated by increasing subsidies from the state budget) with a steady decline in the share of freight transport (mainly in favour of road transport which shows steady growth). On the other hand, however, the share of railways in transport performance expressed in passenger-kilometres/pkm (with a stagnating share of road transport) and tonne-kilometres/tkm (with decreasing share of road transport due to foreign competition), is growing. If we recalculate the data compiled according to the methodology of the Ministry of Transport (in railway transport, these data apply to all carriers but only in the Czech Republic, in the case of a road, air and water transport data refer only to national carriers but including transport to other countries) on the same comparison base according to the EUROSTAT methodology, the rail share will increase by about $20 \%$ in passenger transport and $15 \%$ in freight transport. This is in line with the situation in neighbouring countries and confirms the increasing competitiveness of rail transport with transport distance (the average in the Czech Republic is 
about $52 \mathrm{~km}$ in passenger transport and $164 \mathrm{~km}$ in freight transport, both being about $1 / 3$ higher than road traffic). This is mainly related to falling fixed costs and increasing transport distances. Other influencing factors include, for example, a decrease in the importance of flexibility significance when deciding on the mode of transport or a better offer of opportunities for more efficient use of time in rail passenger transport. Along with the assessment of transport time, it is of course, also necessary to mention the elasticity of demand for long-distance passenger transport. The key role has travel time and price (confirmed by the fact that in the Visegrad countries the price level in longdistance passenger transport in EUR per $\mathrm{km}$ is much lower than in Western Europe). Peng showed a comparative methodological study from 195 researches on demand elasticity in tourism travel (Peng et al., 2015). Regarding more precisely HSR elasticity demand identification due to demand predictions Börjesson (2014) brings after detailed research discussion nested logit model for modal split forecasting between HSR and air transport in Sweden. An important market feature for shaping the demand is the rate of competition and open access approach where market entry of private competitors can bring significant benefits for passengers when the intense price war can reduce average tariffs by $40 \%$ (Tomeš et al., 2016). Price elasticity according to the authors'assessment methodology is closely related to criterion of "usefulness" while regional disparities are much more related to "integration" criterion (see below).

\section{Discussion of a wider context of HSR construction}

In view of the wider European significance of the planned HSR routes, according to the integration criterion, the priority can be ascribed to route B (links to west Germany and then Switzerland, France, and Italy), followed by route $\mathrm{C}$ (links to Austria and further to Hungary and Slovenia), route A (links to north Germany and Scandinavian countries) and route D (links to Poland and Eastern European countries). The main mission of the HSR is, of course, the development of rail passenger transport; freight transport is of secondary importance (in this respect, there is an effective extension of their use at night unattractive to passengers). In line with the concentration of long-distance passenger transport on the HSR, it is also possible to count on the release of the capacity of parallel conventional rail freight lines linked to its acceleration and hence to increase its competitiveness vis-à-vis road transport. According to the current traffic load, the proposed potential routes $\mathrm{A}$ and $\mathrm{C}$ offer the greatest potential in this context. It is useful to supplement the results of the analysis with information from regional passenger transport statistics (Transport Yearbook, 2017). Of the individual regions affected by the planned construction of HSR, the ties between the capital city of Praha and the Středočeský region occupy a dominant position, because 78.9 thousand passengers were transported daily, by trains, in 2017 (in this case, the high intensity of mutual links is primarily determined by the administrative separation of Praha from its hinterland). Ties with the capital, with one exception, also dominate the other affected regions in the order of the Moravskoslezský region - 8,6 thousand persons/day, Olomouc region - 7,8 thousand persons/day, Jihomoravský region $-5,9$ thousand persons/day, Ustecký region - 4,8 thousand persons/day, Plzeňský region - 3,6 thousand persons/day and Region Vysočina - 0,5 thousand persons/day, which, however, shows the strongest ties of 2,6 thousand persons/day with Jihomoravský region.

If we add up the data for all the above-mentioned regions (except only the partially affected Olomouc region, whose centre is located outside the planned HSR routes), we 
reach a total volume of transport of approximately 8.9 million persons/year. According to the analysis performed in the scope of 14 selected routes of the EU, the general threshold of profitability of HSR operations was set at approximately 9 million passengers per year (see European Court of Auditors, 2018). From this information, it is logical to conclude that the potential impact of the HSR network under discussion on the prospective increase in passenger transport in the Czech Republic will not be essential in this context, it is useful to remind that the Czech Republic, for example, has only half the population density compared to Germany. Figure 1 presents the results of the categorization of Czech FUA, which includes major metropolises (Praha), minor metropolises (Brno, Ostrava), middle (non-metropolitan) agglomerations (Plzeň, Olomouc) and small (non-metropolitan) agglomerations (8 remaining regional cities).

It can be seen from Figure 1 that the planned HSR network covers the most important Czech metropolitan and agglomeration areas and, at the same time, connects them with metropolitan areas abroad. An exception is the Liberec agglomeration and further conurbation Pardubice-Hradec Králové, which are not connected to the planned network. It should be noted, however, that this conurbation is in Pardubice connected to I. and II. Transit railway corridor from Praha to Brno and Ostrava (travel time from Pardubice to Praha is about 50 minutes). The remaining regional agglomerations, which will not be directly connected to the planned HSR network, are Ceské Budějovice, Karlovy Vary and, the best situated in this respect, Zlín.

The following table gives a comparison of current and potential travel time in rail and road transport on the relevant routes corresponding to the planned HSR routes, which, with the exception of route D, are related to the start of the journey in Praha (see Table 3 ). While the average real operating speed of intercity trains in the Czech Republic is currently around $100 \mathrm{~km} / \mathrm{h}$ and a maximum speed of $160 \mathrm{~km} / \mathrm{h}$ is permitted on transit railway corridors, the future HSR corridors will significantly increase the speed and correspondingly shorten the journey time ${ }^{3}$. This shortening will logically mean an increase in the competitiveness of rail transport compared to road transport, where an adequate reduction in travel time is not technically feasible.

The lowest current competitiveness of the relevant rail connections compared to car traffic shows the Praha - Jihlava connection (a comparable journey by car saves about $44 \%$ of the time) and further Brno - Katowice (38\%) and Praha - Regensburg - München (37 and 34\%). On the other hand, the highest level of competitiveness is shown by rail transport on the Praha - Ústí n. L connection (only 14\% of travel time savings compared by car) and Praha - Berlin (20\%). When assessing the planned journey time on HSR according to the Program for the development of FC in the Czech Republic (MD, 2017), the greatest potential savings compared to automobile traffic can be expected on the Praha - Ústí n. L and Praha - Jihlava connections (approximately $49 \%$ ) and Brno Ostrava (40\%).

\footnotetext{
${ }^{3}$ The average real operating speeds above $100 \mathrm{~km} / \mathrm{h}$ are achieved only on two railway lines in the Czech Republic: Prague-Pardubice-Olomouc (section from Olomouc to Ostrava is again below $100 \mathrm{~km} / \mathrm{h}$ ) and from Brno to Břeclav (connection to Vienna).
} 
Figure 1. Categorization of Czech FUA

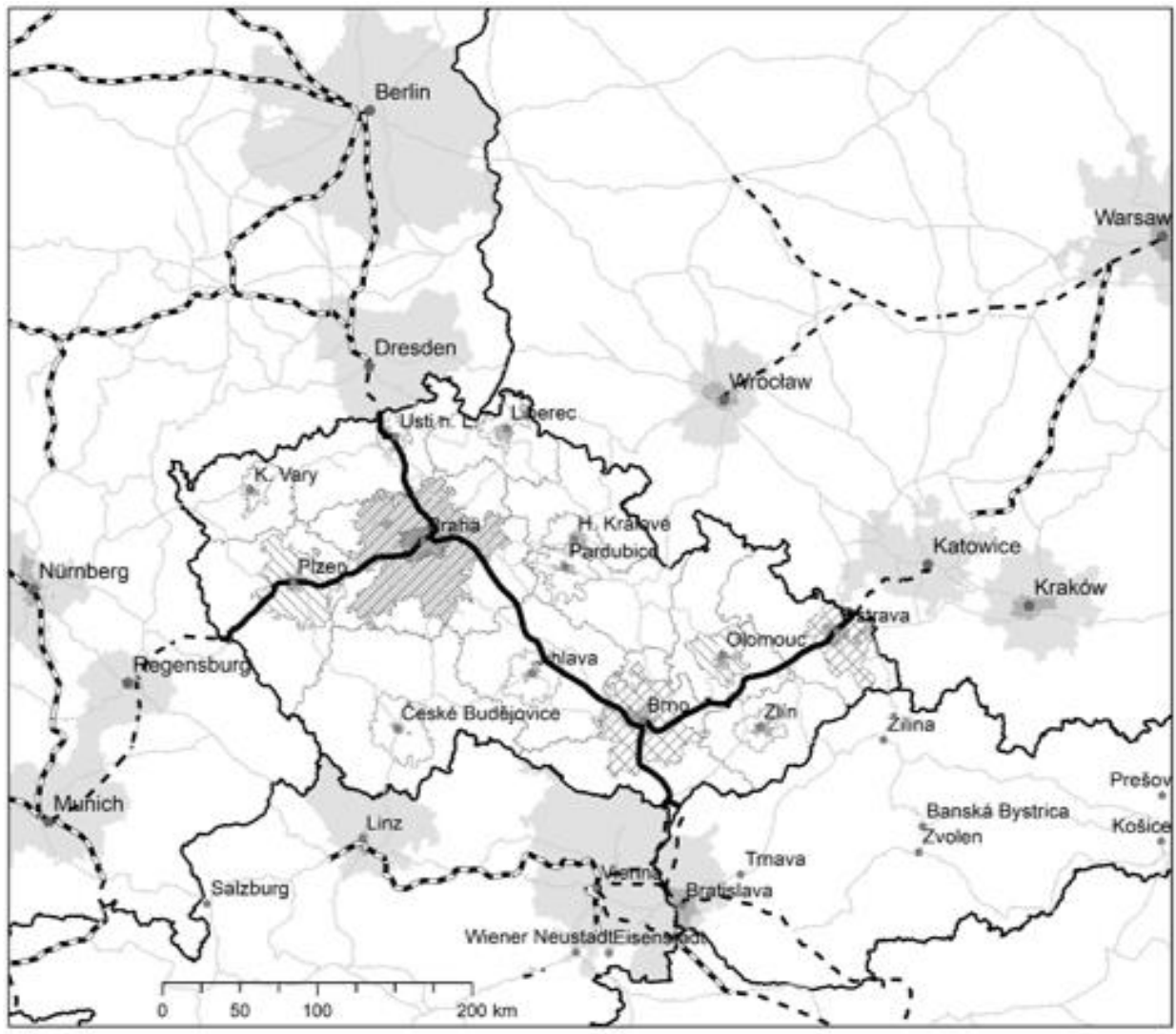

\section{Legend}

Railway type

... HSR in operation

- - HSR planned

- HSR Czech plan

Other railway corridors

CZ NUTS3 regions
Metropolises and agglomerations

282 major metropolises

Q88 minor metropolises

middle agglomerations small agglomerations other

OECD FUA cores (selected)

Source: OECD (2019b), own calculations. 
Table 3. Recent comparison of train and car travel times on HSR routes

$\begin{array}{llllll}\text { metropolis } / \text { other } & \text { travel time by } & \text { travel time by } & \begin{array}{l}\text { travel time } \\ \text { savings - car }\end{array} & \begin{array}{l}\text { planned travel } \\ \text { time by HSR }\end{array} & \begin{array}{l}\text { travel time } \\ \text { savings - HSR } \\ \text { train }\end{array} \\ \text { FUA } & \text { car } & \text { vs. train in } \% & & \text { vs. car in } \%\end{array}$

\begin{tabular}{|c|c|c|c|c|c|}
\hline \multicolumn{6}{|c|}{ Route A } \\
\hline Praha & $\mathbf{x}$ & $x$ & $\mathbf{x}$ & $x$ & $\mathrm{x}$ \\
\hline Ústí n. L. & $1: 09$ & $0: 59$ & 14 & $0: 30$ & 49 \\
\hline Dresden & $2: 11$ & $1: 27$ & 34 & $1: 00$ & 31 \\
\hline Berlin & 4:09 & $3: 20$ & 20 & $2: 58$ & 11 \\
\hline \multicolumn{6}{|c|}{ Route C } \\
\hline Praha & $x$ & $x$ & $x$ & $x$ & $x$ \\
\hline Jihlava & $2: 20$ & $1: 18$ & 44 & $0: 40$ & 49 \\
\hline Brno & $2: 35$ & $1: 58$ & 24 & $1: 15$ & 36 \\
\hline Vienna & $4: 22$ & $3: 19$ & 24 & $2: 30$ & 25 \\
\hline \multicolumn{6}{|c|}{ Route B } \\
\hline Praha & $x$ & $x$ & & & \\
\hline Plzeň & $1: 25$ & $1: 04$ & 25 & $1: 00$ & 6 \\
\hline Regensburg & 4:04 & $2: 33$ & 37 & $2: 11$ & 14 \\
\hline Munich & $5: 36$ & $3: 41$ & 34 & $3: 02$ & 17 \\
\hline \multicolumn{6}{|c|}{ Route D } \\
\hline Brno & $x$ & $x$ & $x$ & & \\
\hline Ostrava & $2: 15$ & $1: 40$ & 26 & $1: 00$ & 40 \\
\hline Katowice & $4: 10$ & $2: 35$ & 38 & $2: 00$ & 23 \\
\hline
\end{tabular}

Source: $\check{C}$ D timetable (2019, mapy.cz. (2019), MD (2017).

For a broader assessment of the potential benefits of the planned HSR construction for the socio-economic integration of the entire Central European macroregion, Figure 2 and following text presents available information on the transport capacities of selected Central European aviation corridors for which the discussed HSR routes are competitive. The analyses show that there are no regular airlines operating on the A - Praha - Berlin and D - Brno - Katowice routes within the winter timetable, suppressing the distorting effects of the summer tourist season (Flightradar, 2018), which would allow calculations with more significant demand shifts from air transport to rail transport. Conversely, the remaining routes B Praha - München and, to a lesser extent, C Praha - Wien have significant potential for further development of air transport. In terms of available transport capacity, these air corridors occupy the second and third strongest positions behind the most frequent Praha - Frankfurt am Main flight connection (Šauer, Pařil, Viturka, 2019). This creates the necessary preconditions for shifting part of the demand from aviation to rail transport (this conclusion also corresponds to the increasing pressure to introduce fuel taxation of environmentally problematic aviation). 
Figure 2. Central European network of HSR and selected airlines from the perspective of the Czech Republic

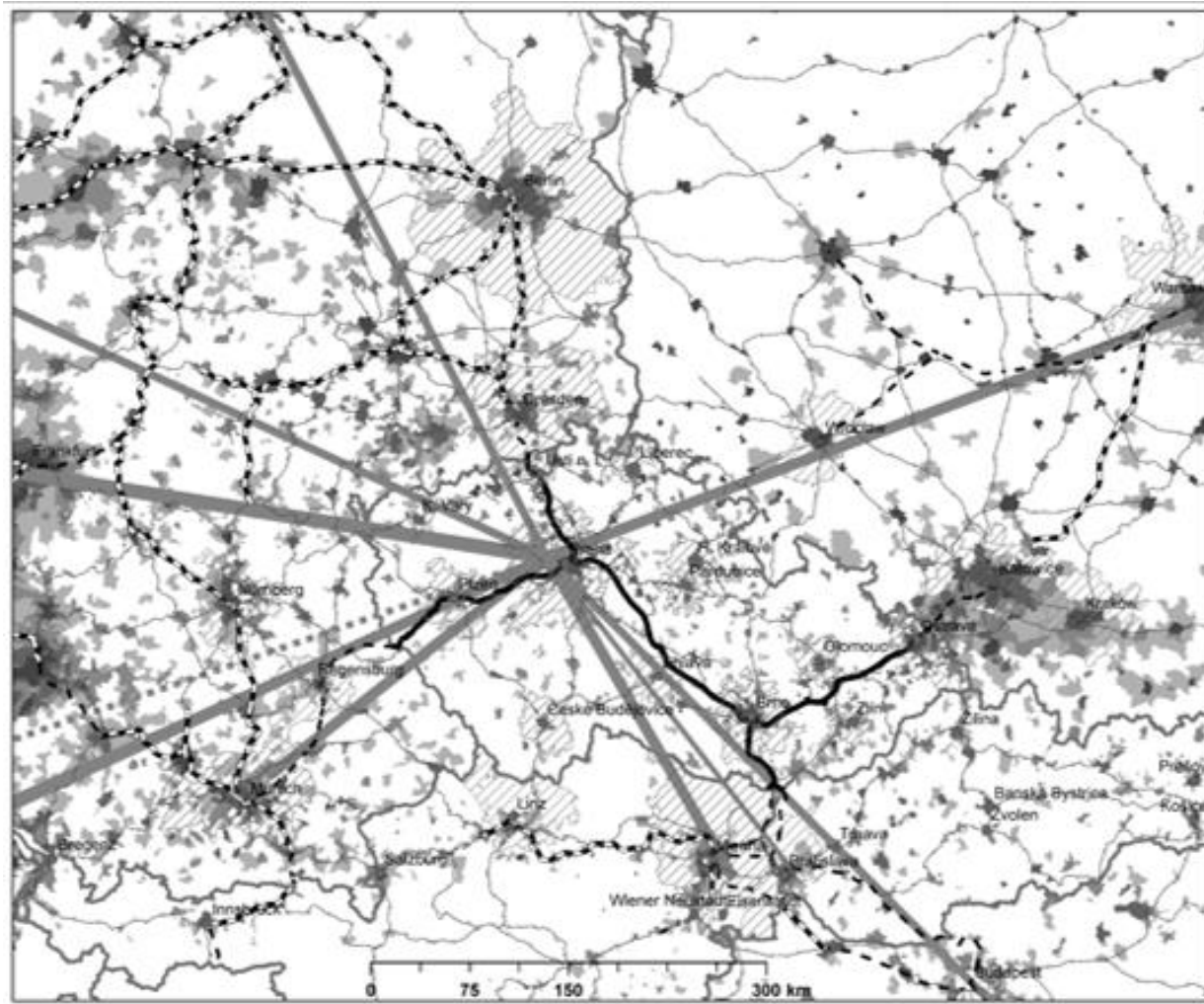

\section{Legend}

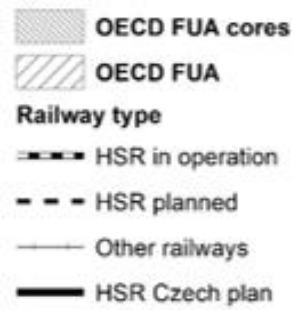

\section{CZ Airlines}

Capacity (th. of seats)

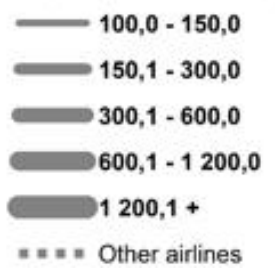

CE Municipalities

Pop. density/km2 2011

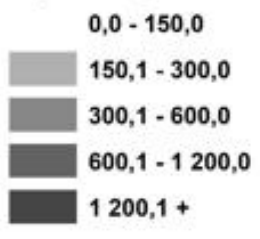

Source: OECD (2019b), Flightradar (2018), own calculations.

Note: HSR Czech plan includes all considered variants of future HSR corridors.

To perceive the socio-economic impacts of HSRs on individual Czech NUTS 3 regions the analysis of their position in the period, 2007-2017 was carried out by means of selected indicators with intensive links to the quality of business and social environment (for this purpose the Středočeský region was merged with Praha into one functional region). Specifically, these indicators are population density, GDP per capita, and unemployment rate, which can be considered as basic indicators of transport demand (its relation to population density per $\mathrm{km}^{2}$ and GDP per capita indicators is direct, in case of unemployment rate this relationship is inverse). Their values in the initial and final year 
of the reference period are given in appendix 1. It is worth noting that although these common indicators are used in many studies as basic information sources for the creation of simulation models, their links to regional development can be strongly differentiated due to the significant influence of inertia (the reporting period also includes different periods of the economic crisis in 2008-2009 and the successive stages of economic recovery and growth). The basic development tendencies of the regions are thus the result of an aggregate impact of a number of diverse factors. Overall, economic growth was accompanied by a significant fall in unemployment, which eventually led to the constitution of regional barriers to labour shortages. If we correlate coefficients of the indicators used, the correlation of population density and GDP per capita (0.534) shows the highest value in accordance with the effect of so-called agglomeration savings. The link between population density and unemployment rate 0.481 -is clearly, and its positive value reflects the difficult restructuring of historically established concentrations of heavy industry near coal districts. In accordance with the well-known Okun's law, the relationship between GDP per capita and unemployment rate indicators shows a negative correlation $(-0.352)$.

The following part is devoted to the issue of convergence of the values examined, the successful solution of which is considered to be the main objective of EU regional policy. Based on the synthesis of the results of partial analyses reflecting changes in the importance of individual regions, the respective development trends were determined. These trends may be, in principle, either convergent character associated with a deconcentrated distribution of phenomena or divergent character associated with a concentrated distribution of phenomena. A key input is a relative position of the region to other regions at the beginning of 2007, on the basis of which the changes that occurred during the period under review were assessed. E.g., in the demonstration case of population density, the starting position of the region is defined by:

$$
\text { PDnrel }=\frac{P D n_{2007}}{P D a v g_{2007}},
$$

where $\mathrm{PD}_{\mathrm{n} 2007}$ is the population of the region in 2007, and $\mathrm{PD}_{\text {avg2007 }}$ is the relevant arithmetic meaning of the indicator in the same year. The development trend is then expressed in a simple relation:

$$
\text { PDntrend }=\frac{P D n_{2017}}{P D n_{2007}}
$$

In terms of potential variants of the combination of values interpreting the starting position of regions and corresponding development trends, the following six model situations may arise, on the basis of which the character of development differentiation of regions and their typology can be summarized (in this context, trend values outside the range of stabilized development tendencies ranging from 0.975 to 1.025 of the mean value are considered essential (with verification intervals for $0.025 / 0.050 / 0.075$ ):

- above average ranking and relative decrease $\rightarrow$ convergence trend - type A1;

- above average ranking and relative growth $\rightarrow$ divergence trend - type A2;

- $\quad$ average ranking with stabilized tendency $\rightarrow$ convergence trend - type B1;

- $\quad$ average ranking with unstabilized tendency $\rightarrow$ divergence trend - type B2;

- below average ranking and relative growth $\rightarrow$ convergence trend - type $\mathrm{C} 1$;

- below average ranking and relative decrease $\rightarrow$ divergence trend - type C2. 
The development of regional differentiation in the period under review can be estimated by the coefficient of variation. In this respect, the prevailing convergence trend was observed for the unemployment rate indicator $(0.325 \rightarrow 0.282)$ and at a significantly lower intensity for the GDP per capita indicator $(0.231 \rightarrow 0.225)$. As far as the remaining population density indicator is concerned, the divergence trend observed $(0.372 \rightarrow$ 0.382) can be considered to be insignificant.

The results of the regional syntheses presented in Table 4 show that the progressive types include the regions of Praha + Středočeský region and the region of Jihomoravský, Plzeňský and Královéhradecký with about $47 \%$ of the population of the Czech Republic. These regions are characterized by an above-average level of GDP per capita and below-average unemployment levels (with the exception of the Jihomoravský region with still unfinished economic restructuring processes). These are mostly migratory attractive regions included in the divergence group 2 with statistically significant positive deviations from average values (the region of the capital city recorded the extremely high level of GDP, which exceeded the average by approximately 3/4), which are, with the exception of the Královéhradecký region, contact with planned HSR routes. Four regions were included in the average type (3 regions including the restructuring Moravskoslezský region belong to the convergence group 1 with about $23 \%$ of the population, compared to the $5 \%$ share of the Pardubický region belonging to the divergence group 2). The remaining five regions are below average or regressive type (3 regions with $15 \%$ of the population belong to the convergence group 1) and two regions with $10 \%$ of the population significantly affected by the displacement of the German population after World War II to the divergence group 2). Progressive/average/regressive position of regions and relevant convergence/divergence trends are listed in more detail in appendix 2 and 3. In general, the presented findings can be interpreted as an integral part of the Czech Republic's political-economic transformation after the Velvet revolution.

Table 4. Typology of regions

type / trend $\quad 1$ - convergence trend

type A - progressive

type B - average

type $\mathrm{C}$ - regressive region, Zlínský region Olomoucký region
2 - divergence trend
Praha + Středočeský region, Jihomoravský region, Plzeňský region, Královéhradecký region

Jihočeský region, Moravskoslezský Pardubický region

Liberecký region, Vysočina region, Ústecký region, Karlovarský region

Source: ČSÚ, MPSV, own calculation.

Note: Regions with the unclear trend are marked in italics.

The fact that four regions of B and C types (Moravskoslezský, Vysočina, Olomoucký, and Ústecký) are linked to the planned HSR routes with a positive impact on deepening their socio-economic integration, can be deemed as positive. Overall, however, we can count on strengthening the position of above-average developed regions, i.e. Prague + 
Středočeský region and Plzeňský together with Jihomoravský regions. From less developed regions we can expect more significant development impulses especially in the case of the Vysočina region (potential travel time savings generated by HSR compared to the current train connection with Prague is about 70\%; significant travel time savings can also be expected in the case of connection Brno - Ostrava). In addition to the above findings, it is worth noting that the decreasing unemployment rate induced by favourable economic developments creates increasing pressures on wage growth with relevant impacts on the purchasing power of the population and GDP growth. These processes, in combination with the monetary policy of the Czech National Bank and other factors, stimulated the rise in prices on the property market, especially in the Praha and Brno metropolitan areas, followed by the Plzen agglomeration. This development is logically accompanied by an increasing distance of commuting to work, copying developments in the most developed countries (however, data for a longer time horizon would have to be available for a more in-depth assessment of the trends). In line with the above conclusions, certain changes in the spatial arrangement of the Czech Republic can be expected, including negative effects known as urban sprawl, with adequate impacts on the transport network configuration.

\section{Conclusion}

The paper provides valuable practical and theoretical-methodological information regarding the evaluation of potential benefits and other economic and non-economic impacts of the planned construction of HSR on the Czech Republic and its regions (including specific impacts, e.g., on the division of transport work). The assessed integration criterion consistently respects space as a primary platform for multi-criteria evaluation of the expediency of the implementation of transport infrastructure construction projects and the subsequent determination of corresponding priorities taking into account the level of business, social, and environment issues. It should be noted that routes A and C appear to be potentially the most advantageous in terms of the examined integration criterion. These routes correspond to a large extent to the two Trans-European Transport Network/TEN-T corridors, the Orient/East-Mediterranean Corridor Hamburg - Athens and the Baltic-Adriatic Corridor Gdańsk - Ravenna, with which route D is also in contact. Route $\mathrm{C}$ and the remaining route $\mathrm{B}$ then follow the Rhine-Danube Corridor Strasbourg - București.

To determine the final priorities for the construction of the HSR from the point of view of regional development, it is, of course, necessary to have the results of analyzes of the other criteria mentioned above. The presented research results significantly extend the information contained in the sectoral concepts of HSR construction and thus reduce the potential risks of inefficient spending of EU funds or state budget (from the system perspective, it is necessary to point out in this connection also the special problem of the simultaneous opening of as many projects as possible motivated by the effort to exhaust the allocated funds regardless of effectiveness). The practical application of the principle of effectiveness emphasizes the synergy of social effects over the one-sided preference of economic effects, which, especially in the case of large projects, stimulates the emergence of suppliers' markets or market oligopolies associated with a significant increase in investment costs. As far as the construction of express transport infrastructure is concerned, the experience so far shows only limited and strongly differentiated 
impacts on the economic development of regions (Körner, 2015; Bray, 1992), which obviously significantly reduces the predictive ability of any future income estimates as a key component of standard cost-benefit analysis. In this context, it should also be pointed out that the construction of HSR can stimulate to some extent the extraction of economic activity from 'rural' regions in favour of metropolitan regions, which is in clear contradiction with promoting convergence as a fundamental principle of EU cohesion policy. Accordingly, it is necessary to state that the application of the multi-criteria approach as a method of their preliminary assessment seems to be irreplaceable, especially in the case of the most demanding transport projects. In our opinion, it is only on this basis possible to arrive at an optimal selection of such solution variants that reflect in a comprehensive way the potential impacts of their implementation. The gained knowledge can also be used in other (especially Central and Eastern European) countries. From a perspective, it should be noted that in future EU programming periods, cross-border transport projects with the highest level of added value from a Union-wide perspective will most likely be preferred (see above). Accordingly, in this case, it is logically possible to consider significantly easier access to financial means from the relevant funds.

In spite of the above comments and conclusions, however, we understand the construction of HSR with regard to the corresponding experience of foreign countries, demonstrating their positive impact on spatial integration and quality of life, as well as international prestige associated with the development of modern transport systems, as very beneficial for the society (UIC, 2019). In this context, however, it is absolutely necessary to take adequate account of the available experience in building the HSR and not to repeat the same conceptual and managerial mistakes made during the construction of the motorway network that has not been completed yet.

Funding: This article is the output of the project called "New Mobility - High-Speed Transport Systems and Transport-Related Human Behaviour", Reg. No. CZ.02.1.01/0.0/0.0/16_026/0008430, co-financed by the "Operational Programme Research, Development and Education".

Disclosure statement: No potential conflict of interest was reported by the authors.

\section{References}

ABATE, M., VIERTH, I., KARLSSON, R., JONG DE G., BAAK, J., (2019). A disaggregate stochastic freight transport model for Sweden. Transportation, 46 (3), 671696. DOI: https://doi. Org/10. 1007/s11116-018-9856-9.

ALBALATE, D., BEL, G., (2010). High-Speed Rail: Lessons for Policy Makers from Experiences Abroad. Universitat de Barcelona: Research Institute of Applied Economics.

ANDERSON, J., (1979). Theoretical Foundation for the Gravity Equation. American Economic Review, 69 (1), 106-116. 
BERIA, P., DEBERNARDI, A., FERRARA, E., (2017). Measuring the long-distance accessibility of Italian cities. Journal of Transport Geography, 62 (C), 66-79. DOI: 10.1016/j.jtrangeo. 2017.05.006.

BERNARD, A.; MOXNES, A.; SAITO, Y., (2019). Production Networks, Geography, and Firm Performance. Journal of Political Economy, 127 (2), 639-688. DOI: $10.1086 / 700764$.

BÖRJESSON, M., (2014). Forecasting demand for high-speed rail. Transportation Research Part A, 70, 81 - 92. DOI: http://dx.doi.org/10.1016/j.tra.2014.10.010.

BRAY, J., (1992). The rush for roads: Road Programme for Economic Recovery? London: Alarm UK, Transport 2000. ISBN 0907347185.

BREZINA, T.; KNOFLACHER, H., (2014). Railway trip speeds and areal coverage. The emperor's new clothes of effectivity? Journal of Transport Geography, 39 (C), 121 130. DOI: 10.1016/j.jtrangeo.2014.06.024.

BREZZI, M., PIACENTINI, M., ROSINA, K, SANCHEZ-SERRA, D., (2012). Redefining urban areas in OECD countries. In Breeze, M. (ed.) Redefining Urban: A New Way to Measure Metropolitan Areas. Paris: OECD Publications. ISBN 9789264174054.

CATS, O., GKIOULOU, Z., (2017). Modelling the impacts of public transport reliability and travel information on passenger's waiting-time uncertainty. EURO Journal on Transportation and Logistics, 6 (3), 247-270. DOI: 10.1007/s13676-014-0070-4. DOI: https://doi.org/10.1007/s13676-014-0070-4.

ČECH, P., (2018). Aktuální stav přípravy rychlých spojení. In Sborník z konference Železnice 2018, Praha: SUDOP.

ČD (2019). Czech Railways Timetables 2019-2020. [online]. [cit. 2019-06-01]. Retrieved from: https://www.cd.cz/jizdni-rad/tratove-jizdni-rady/.

DRUCKER, P., (2001). Management Challenges for the 21st Century. HarperBusiness, 2001. ISBN 0887309992.

ELLEGÅRD, K., SVEDIN, U., (2012). Torsten Hägerstrand's time-geography as the cradle of the activity approach in transport geography. Journal of Transport Geography, 23, 17-25. DOI: https:// doi.org/ 10.1016/ j.jtrangeo.2012.03.023.

EUROPEAN COMMISSION (2011). Roadmap to a Single European Transport Area Towards a competitive and resource efficient transport system. [online]. Brussels: European Commission, [cit. 2019-12-14]. Retrieved from: https://eur-lex. europa.eu/ legalcontent/EN/ALL/?uri=CELEX\%3A52011DC0144

EUROPEAN COURT OF AUDITORS (2018). Special report of the European Court of Auditors on high-speed rail. [online]. [cit. 2019-11-21]. Retrieved from: http://publications. europa. eu/webpub/eca/special-reports/ high-speed-rail- 192018/cs/\# chapter 10.

FEIGENBAUM, B., (2013). High-speed rail in Europe and Asia: lessons for the United States. Policy Study. Reason Foundation, 418, 39 p. 
FLIGHTRADAR (2018). Interactive air transport data provider. [online]. [cit. 2019-0518]. Retrieved from: https://www. Flightradar 24.com/48. 72,639/5.

HALÁS, M., KRAFT, S., (2015). Modelling and prediction of long-distance traffic flows through the example of road transport in the Czech Republic. Scottish geographical journal, 132 (1), 103-117. DOI: https://doi.org/10.1080/ 14702541. 2015. 1084029.

HAZLEDINE, T., (2009). Border effects for domestic and international Canadian passenger air travel. Journal of Air Transport Management, 15(1), 7 - 13. DOI: https://doi.org/10.1016/j.jairtraman.2008.09.007.

HEUERMANN, D. F.; SCHMIEDER, J. F., (2019). The effect of infrastructure on worker mobility: evidence from high-speed rail expansion in Germany. Journal of Economic Geography, 19 (2), 335-372. DOI: 10.1093/jeg/lby019.

HOLLANDER, Y., (2016). Transport Modelling for a Complete Beginner, Gloucester, CTthink!, ISBN 9780995662414.

INTERNATIONAL RAILWAY ASSOCIATION (2007). High-speed railway principles. [online]. [cit. 2019-03-01]. Retrieved from: http://www. brockhaus.de/ buecher /erwachsene/brockhaus_enzyklopaedie/online.php.

JEDLIČKA, J., POSPÍŠIL, K., ŠENK, P., STRIEGLER, R., VANČURA, M., DOSTÁL, I., (2015). Hodnocení prínosů, dopadů a efektivnosti vybraných projektů realizovaných OPD. [Závěrečná zpráva]. Brno: CDV.

KIM, H.; SULTANA, S.; WEBER, J., (2018). A geographic assessment of the economic development impact of Korean high-speed rail stations. Transport Policy, 66 (C), 127-137. DOI: 10.1016/j.tranpol.2018.02.008.

KLODT, H., (2004). Border Effects in Passenger Air Traffic. Kyklos, 57 (4), 519-532. DOI: https://doi.org/10.1111/j.0023-5962.2004.00267.x.

KÖRNER, M., (2013). Vysokorychlostní železniční spojení, současnost a blízký vývoj ve Střední Evropě - územní a ekonomické souvislosti. Urbanismus a územní rozvoj, 16 (5), 46-56.

KÖRNER, M., (2015). Dopravní sítě v kontextu osídlení Česká republika a Střední Evropy. In Sborník z konference Veřejná infrastruktura - doprava a inženýrské sítě. Jeseník: Asociace pro urbanismus a územní plánování České republiky. ISBN 978-8087318-39-3.

MINISTÈRE DE L'ECOLOGIE, DU DÉVELOPPEMENT DURABLE ET DE L'ENERGIE / MEDDE (2015). Dessertes TGV et dynamiques économiques locales: un éclairage à partir de la distinction entre territoires productifs, résidentiels ou intermédiaires. Paris: Rapport final pour le Groupement Opérationnel du Predit

MD (2016). Ministry of Transport of the Czech Republic. Koncepce nákladní dopravy pro období 2017-2023 s výhledem do roku 2030 [online]. [cit. 2018-08-10]. Retrieved from: https://www.mdcr.cz/ attachment/ Media/ Media -a- tiskove -zprávy/Koncepcenakladni-dopravy-pro-obdobi-2017 - \% E2\%80\%93-2023-r/ Koncepce-nakladnidopravy. pdf.aspx 017/. 
MD (2017). Ministry of Transport of the Czech Republic. Program rozvoje rychlých železničních spojení. [online]. [cit. 2018-09-12]. Retrieved from: https://www. mdcr. cz/ Dokumenty/Strategie/ Vysokorychlostni-trate.

NASH, Ch., (2015). When to invest in high speed rail. Journal of Rail Transport Planning \& Management, 5(1), DOI: 10. 1016/j.jrtpm.2015.02.001.

OECD (2013). Definition of functional urban areas for the OECD metropolitan database. [online]. [cit. 2018-07-29]. Retrieved from: http: www. oecd. org.

OECD (2019a). Metropolitan areas. [online]. [cit. 2019-07-29]. Retrieved from: https://stats. oecd. org/ Index.aspx? DataSet Code = CITIES.

OECD (2019b). Functional urban areas in OECD countries. [online]. [cit. 2019-08-25]. Retrieved from: http: www. oecd. org.

PENG, B., SONG, H., CROUCH, G. I., WITT, S. F., (2015). A Meta-Analysis of International Tourism Demand Elasticities. Journal of Travel Research, 54 (5), 611- 633. DOI: https://doi.org/10.1177/0047287514528283.

ROČENKA DOPRAVY ČESKÉ REPUBLIKY (2017). Transport Yearbook in the Czech Republic [online]. [cit. 2019-07-10]. Retrieved from: https://www. sydos. cz.cs/ rocenka $-2017 /$ rocenka/htm_cz/index.html.

SEIDENGLANZ, D., (2009). Competitiveness of rail and air transport (Konkurenceschopnost železniční a letecké dopravy). In Konkurenceschopnost a konkurence v železniční dopravě. Brno: Masaryk University. ISBN 978-80-210-5008-2.

SHIQUI , L., MAOXIANG, L., XUEQIAO Y., MINGYUE Z., MINGHE J., SANGBING T., CHENG-KUANG W., FANG, B., (2019). A Sustainable Transport Competitiveness Analysis of the China Railway Express in the Context of the Belt and Road Initiative. Sustainability, 11 (10), 2896. DOI: 10.3390/su11102896.

SZCZURASZEK, T., IWANOWICZ, D., (2018). Conditionings of Regional Railway Transport in Poland on the Example of a Selected Area. IOP Conference Series: Materials Science and Engineering, 471(5). DOI: 10.1088/1757-899X/471/6/062020.

SŽDC (2018). Správa železniční dopravní cesty. Plánovaná sít' vysokorychlostních koridorů v České republice. [online]. [cit. 2019-09-17]. Retrieved from: https://www.vysokorychlostni-zeleznice.cz/ ministerstvovysokorychlostni-zeleznice-v$\mathrm{cr} /$.

ŠAUER, M., PARIL, V., VITURKA, M., (2019). Integrative potential of Central European metropolies with a special focus on the Visegrad countries. Technological and Economic Development of Economy, 25 (2), 219-238. DOI: 10. 3846/ tede. 2019.7555.

ŠLEGR, P. a kol., (2012). Rychlá železnice i v České republice. Praha: CEDOP. ISBN 978-80-905005-0-1.

THE FEDERAL STATISTICAL OFFICE OF GERMANY (2018). Das Statistische Bundesamt, Wiesbaden. [online]. Retrieved from: https://www.destatis.de/EN/ Homepage.html. 
TOMEŠ, Z., KVIZDA, M., JANDOVÁ, M., REDERER, V., (2016). Open access passenger rail competition in the Czech Republic. Transport Policy, 47 (2), 203-211. DOI: http://dx.doi.org/10.1016/j.tranpol.2016.02.003.

TÝFA, L., (2012). Vysokorychlostní železnice ve světě v posledních letech (II). Silnice a železnice, 7 (2), s. 17-20. ISSN 1801-822X.

UIC, 2019. Union International Des Chemins De Fer. High Speed Lines in the World. [online]. [cit. 2019-07-29]. Retrieved from: https:// uic. org/ IMG/pdf/20190328_ high_ speed_lines_in_the_world.pdf.

VITURKA, M., (2011). Integration Theory of Sustainable Regional Development Presentation and Application. Politická ekonomie, 59 (6), 794-809, ISSN 0032-3233. DOI: $10.18267 /$ j.polek.822.

VITURKA, M., PAŘIL, V., TONEV, P., ŠAŠINKA P., KUNC J., (2015). The Metropolisation Processes - A Case of Central Europe and the Czech Republic. Prague Economic Papers, 26 (5), 505-522. ISSN 2336-730X. DOI: 10. 18267/ j.pep.624.

VITURKA, M.; PAŘIL, V., (2015). Regional assessment of the effectiveness of road infrastructure projects. International journal of transport economics, 42 (4), 507-528. DOI: $10.1400 / 238068$.

WETWITOO, J., KATO, H., (2019). Regional and Local Economic Effects from Proximity of High-Speed Rail Stations in Japan: Difference-in-Differences and Propensity Score Matching Analysis. Transportation Reseatrch Record, 25 (9), 323-333. DOI: $10.1177 / 0361198119844757$

WOOD, A., (1994). North-South Trade, Employment and Inequality: Changing Fortunes in a Skill-Driven World. Oxford: Clarendon Press

XU, F., (2018). The Belt and Road: The Global Strategy of China High-Speed Railways. Singapore: Springer. ISBN 978-981-13-1104-8.

ZURKOWSKI, A., (2018). High-Speed Rail in Poland - Advances and Perspectives. CRC Press/Balkema. ISBN 9781138544697. 
Appendix 1: Development of selected indicators for regions in the period 2007/2017

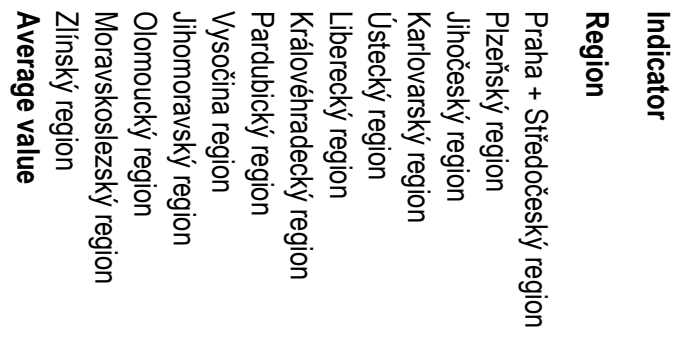

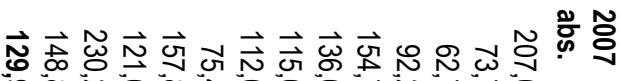

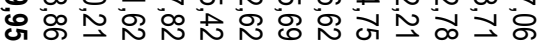

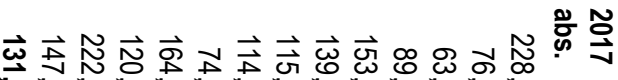
귕

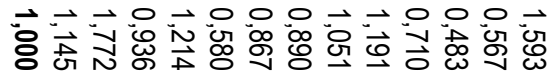

$$
\text { 뭄 }
$$

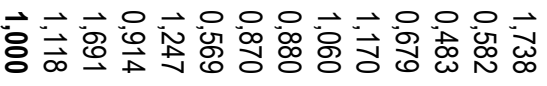

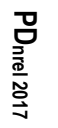

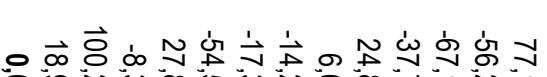

을 농

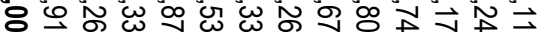
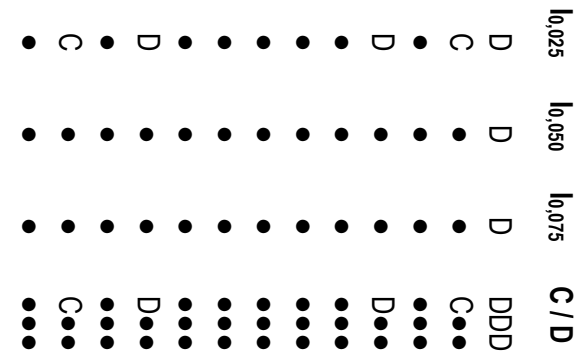


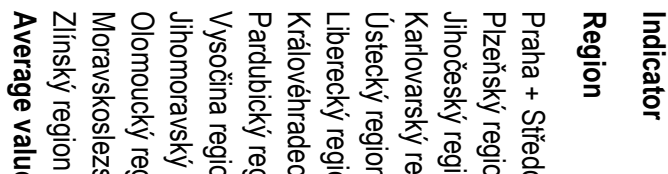

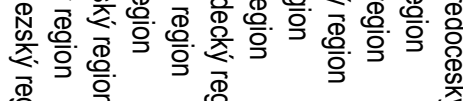
흥. 흠

ㅈ.

$\stackrel{\overline{0}}{\overline{0}}$

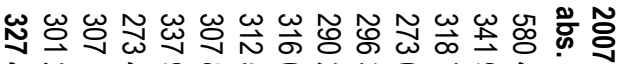
청 겅

苛古黛

깅

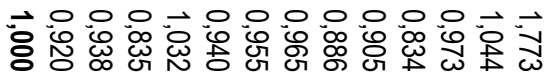

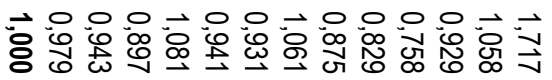

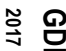

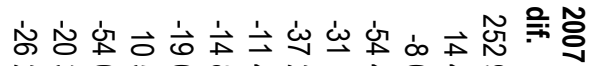

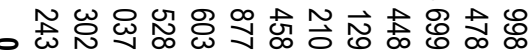

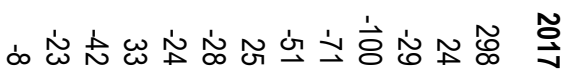
임 구

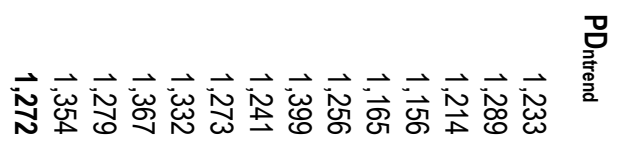

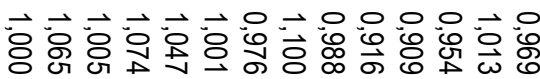
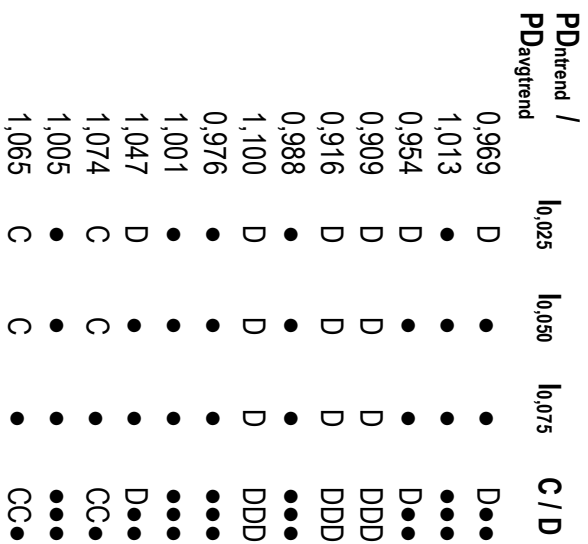


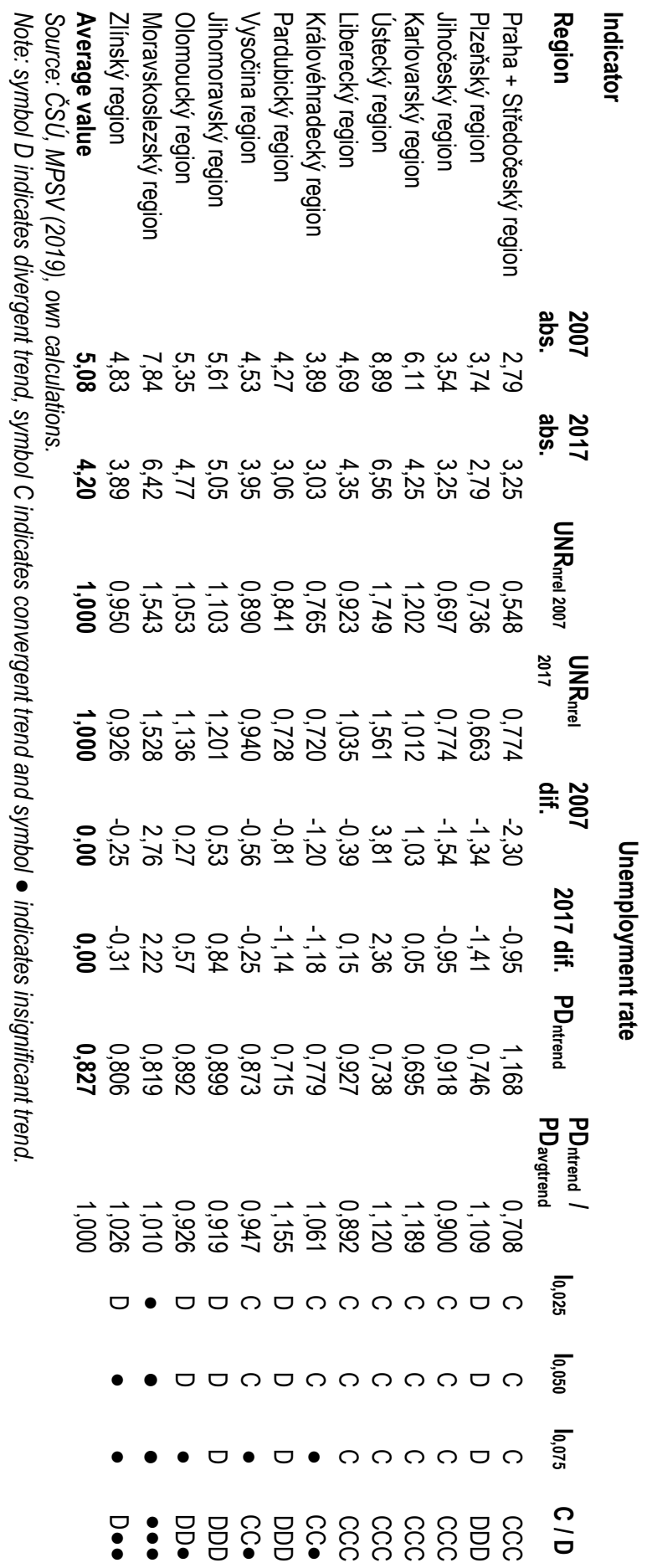


Appendix 2: Regional classification according to population density, GDP per capita and unemployment rate 2007/2017

\begin{tabular}{lcccccccc} 
Indicator & \multicolumn{2}{c}{ PD } & \multicolumn{7}{c}{ GDP/C } & UR & & \\
Region & $\mathbf{2 0 0 7}$ & $\mathbf{2 0 1 7}$ & $\mathbf{2 0 0 7}$ & $\mathbf{2 0 1 7}$ & $\mathbf{2 0 0 7}$ & $\mathbf{2 0 1 7}$ & Sum & R/A/P \\
\hline Praha + Středočeský region & 2 & 1 & 1 & 1 & 1 & 4 & 10 & $\mathbf{P}$ \\
Královéhradecký & 8 & 8 & 5 & 3 & 4 & 2 & 30 & $\mathbf{P}$ \\
Jihomoravský & 3 & 3 & 3 & 2 & 10 & 11 & 32 & $\mathbf{P}$ \\
Plzeňský & 12 & 11 & 2 & 4 & 3 & 1 & 33 & $\mathbf{P}$ \\
Zlínský & 5 & 5 & 9 & 5 & 8 & 6 & 38 & $\mathbf{A}$ \\
Pardubický & 9 & 9 & 6 & 8 & 5 & 3 & 40 & $\mathbf{A}$ \\
Moravskoslezský & 1 & 2 & 8 & 6 & 12 & 12 & 41 & $\mathbf{A}$ \\
Jihočeský & 13 & 13 & 4 & 9 & 2 & 5 & 46 & $\mathbf{A}$ \\
Liberecký & 6 & 6 & 11 & 11 & 7 & 9 & 50 & $\mathbf{R}$ \\
Vysočina & 11 & 12 & 7 & 7 & 6 & 7 & 50 & $\mathbf{R}$ \\
Olomoucký & 7 & 7 & 12 & 10 & 9 & 10 & 55 & $\mathbf{R}$ \\
Ústecký & 4 & 4 & 10 & 12 & 13 & 13 & 56 & $\mathbf{R}$ \\
Karlovarský & 10 & 10 & 13 & 13 & 11 & 8 & 65 & $\mathbf{R}$
\end{tabular}

Source: ČSÚ, MPSV (2019), own calculations.

Appendix 3: Regional grouping 2007/2017

\begin{tabular}{|c|c|c|c|c|c|c|}
\hline Region & $\begin{array}{l}\text { Regressive/ } \\
\text { Average/ } \\
\text { Progressive }\end{array}$ & PD & GDP/C & UR & $\begin{array}{l}\text { Convergencel } \\
\text { Divergence }\end{array}$ & Group \\
\hline Praha + Středočeský region & $\mathbf{P}$ & DDD & $\mathrm{D} \bullet \bullet$ & $\mathrm{CCC}$ & D & A2 \\
\hline Plzeňský & $\mathbf{P}$ & $C \bullet \bullet$ & $\bullet \bullet \bullet$ & DDD & D & $\mathrm{A} 2$ \\
\hline Jihočeský & A & $\bullet \bullet \bullet$ & $\mathrm{D} \bullet \bullet$ & $\mathrm{CCC}$ & C & B1 \\
\hline Karlovarský & $\mathbf{R}$ & $\mathrm{D} \bullet \bullet$ & DDD & $\mathrm{CCC}$ & D & $\mathrm{C} 2$ \\
\hline Ústecký & $\mathbf{R}$ & $\bullet \bullet \bullet$ & DDD & $\mathrm{CCC}$ & D & $\mathrm{C} 2$ \\
\hline Liberecký & $\mathbf{R}$ & $\bullet \bullet \bullet$ & $\bullet \bullet \bullet$ & $\mathrm{CCC}$ & C & $\mathrm{C} 1$ \\
\hline Královéhradecký & $\mathbf{P}$ & $\bullet \bullet \bullet$ & DDD & $\mathrm{CC} \bullet$ & D & A2 \\
\hline Pardubický & A & $\bullet \bullet \bullet$ & $\bullet \bullet \bullet$ & DDD & D & B2 \\
\hline Vysočina & $\mathbf{R}$ & $\bullet \bullet \bullet$ & $\bullet \bullet \bullet$ & $\mathrm{CC} \bullet$ & C & $\mathrm{C} 1$ \\
\hline Jihomoravský & $\mathbf{P}$ & $\mathrm{D} \bullet \bullet$ & $\mathrm{D} \bullet \bullet$ & DDD & D & A2 \\
\hline Olomoucký & $\mathbf{R}$ & $\bullet \bullet \bullet$ & $\mathrm{CC} \bullet$ & $\mathrm{DD \bullet}$ & C & C1 \\
\hline Moravskoslezský & A & $C \bullet \bullet$ & $\bullet \bullet \bullet$ & $\bullet \bullet \bullet$ & C & B1 \\
\hline Zlínský & A & $\bullet \bullet \bullet$ & $\mathrm{CC} \bullet$ & $\mathrm{D} \bullet \bullet$ & C & B1 \\
\hline
\end{tabular}

